\title{
梯 New Disease Reports \\ First report of Pepper yellow vein Mali virus associated with pepper yellow vein disease in Cote d'Ivoire
}

\author{
K. Séka ${ }^{1,2}$, A. Ouattara ${ }^{1,3}$, K.P. Assiri ${ }^{2}$, K.D. Kra ${ }^{2}$, M. Hoareau ${ }^{1}$, P. Lefeuvre ${ }^{1}$, H. Atta Diallo ${ }^{2}$ and J.M. Lett $^{1 *}$ \\ ${ }^{1}$ CIRAD, UMR PVBMT, Pôle de Protection des Plantes, 97410 Saint-Pierre, lle de La Réunion, France; ${ }^{2}$ Université Nangui \\ Abrogoua, 02 BP 801 Abidjan, Côte d'Ivoire; ${ }^{3}$ INERA, LMI Patho-Bios, 01 BP 476, Ouagadougou 01, Burkina Faso
}

*E-mail: lett@cirad.fr

Received: 27 Jan 2017. Published: 27 Feb 2017.

In Mali (Zhou et al., 2008) and Burkina Faso (Tiendrébéogo et al., 2008), pepper yellow vein disease (PYVD) is associated with the African monopartite begomovirus Pepper yellow vein Mali virus (PepYVMLV).

In January 2012 and August 2013, severe yellowing, leaf curling and deformation symptoms (Fig. 1), resembling those of PYVD were observed on pepper (Capsicum spp.) across Côte d'Ivoire (Table 1). Twenty leaf samples from pepper plants with symptoms were collected and tested for the presence of begomoviruses using a PCR assay with a set of degenerate primers designed to amplify the coat protein gene of Old World begomoviruses (Seka et al., 2016). PCR products of the expected size were obtained from seven samples, suggesting the presence of Old World monopartite begomoviruses (Table 1).

PCR-positive samples were further processed and viral genome sequences were amplified from three samples (Table 1) by rolling-circle amplification, cloned using the restriction enzyme BamHI and sequenced. The three genome sequences were 2,786 nucleotides in length (GenBank Accession Nos. KY271075-KY271077) and showed the highest pairwise sequence identity, 98 to 99\%, with PepYVMLV isolates from Burkina Faso (PepYVMLV-[BF:Oua:sweet pepper1:08]; FM876849) and Mali (PepYVMLV-[ML:03]; AY502935). A maximum-likelihood phylogenetic tree constructed with publicly available begomovirus genome sequences (MEGA6; Tamura et al., 2013), confirmed the genetic relationship of the Côte d'Ivoire isolates of PepYVMLV with isolates from neighbouring Burkina Faso and Mali (Fig. 2).

To our knowledge, this is the first report of PepYVMLV associated with PYVD in Côte d'Ivoire. Our results confirm the geographical distribution of PepYVMLV in West Africa and the close genetic relationship of this

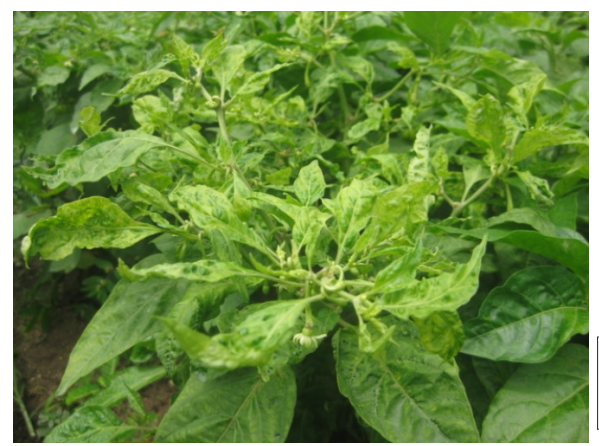

Figure 1

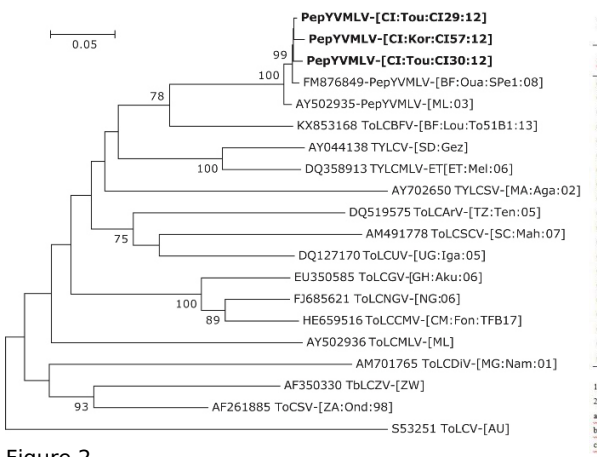

Figure 2 viral population (Tiendrébéogo et al., 2008).

\section{Acknowledgements}

This study was funded by the Région Réunion, the European Union (FEDER) and CIRAD. K. Séka is a recipient of a fellowship from CIRAD (Action incitative renforcement des compétences des chercheurs du Sud).

\section{References}

Séka K, Ouattara A, Assiri KP, Kra KD, Hoareau M, Lefeuvre P, Diallo HA, Lett J-M, 2016. First report of Cotton leaf curl Gezira virus and Okra yellow crinkle virus associated with okra leaf curl disease in Côte d'Ivoire. New Disease Reports 34, 8.

http://dx.doi.org/10.5197/j.2044-0588.2016.034.008

Tamura K, Stecher G, Peterson D, Filipski A, Kumar S, 2013. MEGA6: Molecular Evolutionary Genetics Analysis Version 6.0. Molecular Biology and Evolution 30, 2725-2729. http://dx.doi.org/10.1093/molbev/mst197

Tiendrébéogo F, Traoré VSE, Barro N, Traoré AS, Konaté G, Traoré O, 2008. Characterization of Pepper yellow vein Mali virus in Capsicum sp. in Burkina Faso. Plant Pathology Journal 7, 155-161. http://dx.doi.org/10.3923/ppj.2008.155.161

Zhou YC, Noussourou M, Kon T, Rojas MR, Jiang H, Chen LF, Gamby K, Foster R, Gilbertson RL, 2008. Evidence of local evolution of tomatoinfecting begomovirus species in West Africa: characterization of tomato leaf curl Mali virus and tomato yellow leaf crumple virus from Mali. Archives of Virology 153, 693-706 http://dx.doi.org/10.1007/s00705-008-0042-9

To cite this report: Séka K, Ouattara A, Assiri KP, Kra KD, Hoareau M, Lefeuvre P, Atta Diallo H, Lett JM, 2017. First report of Pepper yellow vein Mali virus associated with pepper yellow vein disease in Cote d'Ivoire. New Disease Reports 35, 11. http://dx.doi.org/10.5197/j.2044-0588.2017.035.011 